\title{
Indonesian Journal of Contemporary Management Research

\section{The Effect of Shopee e-Service Quality and Price Perception on Repurchase Intention: Customer Satisfaction as Mediation Variable}

\author{
Rohwiyati Rohwiyati ${ }^{1 *}$, Praptiestrini Praptiestrini ${ }^{2}$ \\ ${ }^{1}$ Faculty of Economics, Universitas Surakarta, Surakarta, Indonesia \\ ${ }^{2}$ Faculty of Economics, Universitas Surakarta, Surakarta, Indonesia
}

\begin{tabular}{|c|c|}
\hline Submission Info & Abstract \\
\hline $\begin{array}{r}\text { Received } 28 \text { November } 2018 \\
\text { Revised 20 J anuary } 2019 \\
\text { Accepted 25 January } 2019\end{array}$ & $\begin{array}{l}\text { The study is aimed to analyze the effect of e-service quality (e- } \\
\text { SERVQUAL) and price perception on repurchase intention to } \\
\text { consume Shopee product in Solo City with satisfaction as }\end{array}$ \\
\hline $\begin{array}{r}\text { Keywords } \\
\text { e-SERVQUAL } \\
\text { price perception } \\
\text { satisfaction } \\
\text { repurchase intention }\end{array}$ & $\begin{array}{l}\text { questionnaires. Population in this study are customers in Solo city } \\
\text { who make purchases through e-commerce Shopee. Samples of } \\
100 \text { customers are chosen by purposive sampling method. } \\
\text { Methods analysis used is path analysis. Research findings } \\
\text { revealed that e-SERVQUAL, price perception, and customer } \\
\text { satisfaction have positive and significant effect on repurchase } \\
\text { intention. Results of Sobel test show that customer satisfaction } \\
\text { mediates the effect of e-SERVQUAL on repurchase intention, but } \\
\text { customer satisfaction cannot mediate the effect of price } \\
\text { perception on repurchase intention. }\end{array}$ \\
\hline
\end{tabular}

(C) 2019 IJ CMR. All rights reserved.

\section{Introduction}

In general, e-commerce businesses in Indonesia can be divided into five different forms, namely classifieds, customer to customer marketplace, shopping mall, business to consumer and social media shop. The form of business classifieds (list of classified ads) is a web e-commerce service provider that is not involved or facilitates directly online buying and selling transactions that take place. In the form of business classifieds, ecommerce companies only become media that bring together sellers and buyers in one place.

At present one of the fastest growing e-commerce in Indonesia is Shopee. Shopee is an online-based shopping platform that provides a wide range of sales products ranging from electronics, household appliances, clothing, accessories to fashion. In addition to providing a variety of products, another advantage of Shopee is that the buyer can return goods or funds if the goods received are not as desired. Users can also

\footnotetext{
*Corresponding Author: Rohwiyati Rohwiyati - rohwiyatiunsa1978@gmail.com. Faculty of Economics, Universitas Surakarta, Surakarta, Indonesia.

Recommended Citation: Rohwiyati, R., \& Praptiestrini, P. (2019). The Effect of Shopee e-Service Quality and Price Perception on Repurchase Intention: Customer Satisfaction as Mediation Variable. Indonesian Journal of Contemporary Management Research, 1(1), 47-54.
} 
find items easily in the search field simply by entering a picture of the item being searched for. Shopee also provides a free postage feature for shipping goods. By ranking fourth in the e-commerce search category that is most in demand by users in the Top 40 e-commerce with a total of 34,510,800 visitors each month (Meidita et al., 2018).

Loyalty to an object, such as a brand, store, service, or company that is shown by behavioral tendencies or attitudinal (psychological) that are beneficial to the object (East et al., 2005). Behavioral intention is an important reference for marketers in achieving marketing success. Clemes et al. (2009) states that behavioral intention relates to the length of the company's relationship with customers and customer loyalty. According to Oliver (1999) behavioral intention or intention to behave synonymous with conative loyalty, namely the commitment of customers to make purchases. Behavioral intention is positively indicated by repurchase intention, while behavioral intention is negatively like complaining behavior or moving to another brand/company. Repurchase intention is the intention of someone to repurchase a product or service by considering previous experience in using the product or service (Hellier et al., 2003).

One of the factors that influence repurchace intention is the quality of services provided by producers. According to Payne (1993) service quality is the ability of an organization to meet or exceed customer expectations. Improving service quality through SERVQUAL dimensions (tangibles, reliability, responsiveness, assurance, empathy) can be used as a marketer's strategy to establish long-term relationships with customers. Study of Srivastava \& Sharma (2013) proves that service quality has a positive effect on repurchase interest. Other research findings that provide empirical evidence regarding the effect of service quality on repurchase intention are (Hellier et al., 2003; Srivastava \& Sharma, 2013; Idris, 2017). The quality of services in the online environment is important in determining the success or failure of electronic commerce.

Chase \& Aquilano (2004) said that e-service quality is a service provided to consumers of internet networks as an extension of the ability of a site to facilitate shopping, purchasing, and distribution activities effectively and efficiently. According to Parasuraman et al. (2005) define e-service quality as the extent to which a website is able to facilitate consumer activities including shopping, purchasing, and shipping both products and services efficiently and effectively. One of the most widely used models is the e-SERVQUAL model developed by Zeithaml et al. (2002). From the SERVQUAL traditional model (Zeithaml et al., 2002), succeeded in developing the five main dimensions of service quality, into seven e-SERVQUAL dimensions described by Tjiptono \& Chandra (2016), namely efficiency, reliability, fulfillment, privacy, responsiveness, compensation, and contact. The results showed a positive effect of eSERVQUAL on repurchase intention and customer loyalty (J onathan, 2013; Laurent, 2016; Akbar \& Djatmiko, 2016; Idris, 2017). In addition to service quality, repurchase intention is also influenced by price perceptions. Price factors can affect repurchase intention of consumers, the intended factor is the suitability of prices with the quality and quantity obtained (Zeithaml et al., 2017). Based on research conducted by Faradiba (2013); Idris (2017) proves that price perception has a positive effect on repurchasing interest.

The relationship between customer satisfaction and repurchase interest has attracted researchers, which states that there is a positive influence on customer 
satisfaction with repurchasing interest. Kotler \& Keller (2016) define customer satisfaction as consumers' happy feelings that arise after comparing the real performance of a product with their expectations. Customers who feel satisfied tend to find it difficult to change their choices. According to Ho \& Lee (2007), the level of customer satisfaction in electronic services can be measured when a customer makes an online purchase on a website, makes the right choice by making a purchase on the website, and feels satisfied every time he makes a purchase on the website.

According to Hellier et al. (2003) customer satisfaction has a positive effect on repurchasing interest. This is also supported by research conducted by Srivastava \& Sharma (2013) which indicates a positive influence between customer satisfaction and repurchase interest. Other findings indicate that service quality and price perimeter can affect repurchase intention through customer satisfaction, in other words the influence of service quality and price perception on repurchase intention is mediated by customer satisfaction. This is supported by research conducted by Kuo \& Tang (2013); Idris (2017).

Based on the description, satisfaction can be used as a company strategy to maintain customers who can then increase company profits. Satisfaction can encourage repurchase intention. E-commerce service quality, and satisfaction, price is an important reference for e-commerce companies in achieving profitability. As with conventional marketing, Shopee as an e-commerce company seeks to satisfy customers through quality information services. If customers feel satisfied with the price and service information, they will again entrust their needs to the e-commerce company. Behavior for satisfied online customers will more often visit the website that can be trusted, and encourage the intention to repurchase.

The main problem in this study, that until now there has been no research that has developed a model of the four constructs in the context of e-commerce Shopee in Solo City. To fill this gap, this study aims to develop a model to test the causality relationship between e-SERVQUAL Shopee factors, price perception, and customer satisfaction by repurchase intention to customers in Solo City.

\section{Methods}

This type of research is survey research using a quantitative approach, where data analysis is carried out in this study by performing statistical calculations. The design of this study is an explanatory type that is to explain the causal relationship between variables through hypothesis testing. The population in this study were all Shopee customers in Solo City, using a sample of 100 customers. Sampling uses a purposive sampling technique, the criteria for which are determined that customers have purchased Shopee products at least twice.

This study uses four instruments including e-SERVQUAL, price perception, customer satisfaction and repurchase intention. E-SERVQUAL is the customer's perception of the quality of electronic services provided by Shopee companies to meet customer expectations. Tjiptono \& Chandra (2016) developed seven dimensions to measure e-SERVQUAL namely efficiency, reliability, fulfillment, privacy, responsiveness, compensation, and contact. Price perception is the customer's assessment of the price of products offered by Shopee companies. Price perception is measured by three 
dimensions, namely affordability, price compatibility with quality, and price lower than competitors (Martin - Consuegra et al., 2007; Idris, 2017). Customer satisfaction is the result of customer evaluation of Shopee electronic products and services that have been consumed to meet customer needs and desires. Customer satisfaction is measured in five dimensions, namely satisfaction with electronic services, security, price, emotional factors, and convenience (Laurent, 2016). Repurchase intention is the intention of someone to repurchase a product or service by considering previous experience in using the product or service (Hellier et al., 2003). Repurchase intention is measured by dimensions namely transactional interest, explorative interest, referential interest, and preferential interest (Idris, 2017).

Data collection technique using questionnaire that is measured by likert scale five point namely Strongly Agree (5), Agree (4), Neutral (3), Disagree (2). Strongly Disagree (1). To test the quality of the data tested the validity and reliability of the instrument. Data analysis techniques using path analysis aims to determine the effect of eSERVQUAL and the perception of prices towards repurchase intention mediated customer satisfaction.

\section{Results and Discussion}

Respondents of this study are 100 customers who ever consume Shopee product in Solo. Descriptive characteristics of respondents shows that male of $34.2 \%$ and female of $65.8 \%$; age $<25$ years of $59.9 \%, 26-40$ years of $26.8 \%, 41-60$ years of $13.4 \%$; student of $20.8 \%$, civil servants of $6.7 \%$, self-employed of $36.6 \%$, private of $35.9 \%$; high school education of $56 \%, \mathrm{D} 3 / \mathrm{D} 4$ of $12 \%$, S1 of $21.5 \%$, S2 of $10.6 \%$; income $<1$ million of $21.8 \%$, $1-3$ million of $39.4 \%$ and $>3$ million of $38.7 \%$.

Based on data processing shows that all items, of e-SERVQUAL, price perceptions, customer satisfaction and repurchase intention have a good level of validity (Table 1). The reliability test results show that all instruments have cronbach alpha values $\geq 0.6$ (Table 1). Thus all of the research instruments have good reliability. Based on the classical assumption test this research model has fulfilled the assumption test required by the regression model, that is fulfilling the requirements of multicollinearity test, heteroscedasticity test, autocorrelation test, and normality test.

The results of the multicollinearity test show that all independent variables (eSERVQUAL, price perception, and customer satisfaction) are not linearly correlated. This is indicated by tolerance values $>0.1$ and VIF $<10$ (Table 2). Thus, this research model does not occur multicollinearity. The results of heteroscedasticity test show that all independent variables (e-SERVQUAL, price perception, and customer satisfaction) have no significant effect on the residual absolute variables (Table 2 ). This is indicated by the significance value $>0.05$, meaning that the study model did not occur with heteroscedasticity problems. Results of autocorrelation test through Runs test were obtained by asymp. sig. (2-tailed) $>0.05$ (Table 2). Thus this research model does not have an autocorrelation problem. Results of normality test through the kolmogorovsmirnov test obtained asymp. sig. (2-tailed) $>0.05$ means normal residuals (Table 2 ). 
Table 1 Result of Validity and Reliability Testing

\begin{tabular}{llcc}
\hline \multicolumn{1}{c}{ Variables } & \multicolumn{1}{c}{ Dimensions } & $\begin{array}{c}\text { Corrected Item- } \\
\text { Total Correlation }\end{array}$ & Cronbach Alpha \\
& Efficiency & 0.834 & 0.965 \\
& Reliability & 0.894 & \\
& Fulfillment & 0.902 & \\
& Privacy & 0.898 & \\
& Responsiveness & 0.870 & \\
& Compensation & 0.884 & 0.864 \\
Price Perception & Contact & 0.857 & \\
& Affordability & 0.796 & \\
Customer Satisfaction & Price compatibility with quality & 0.722 & 0.948 \\
& Price lower than competitors & 0.715 & \\
& Electronic services & 0.784 & \\
& Security & 0.825 & 0.935 \\
& Price & 0.928 & \\
Repurchace Intention & Emotional factors & 0.909 & \\
& Convenience & 0.856 & \\
& Transactional interest & 0.873 & \\
& Explorative interest & 0.857 & \\
& Referential interest & 0.820 & \\
& Preferential interest & 0.844 & \\
\hline
\end{tabular}

Table 2 Result of Classical Assumption Test

\begin{tabular}{lll}
\hline \multicolumn{1}{c}{ Classical Assumption Test } & \multicolumn{1}{c}{ Results } & \multicolumn{1}{c}{ Explanation } \\
\hline Multicollinearity test & Tolerance $(0.943 ; 0.956 ; 0.904)>0.1$ & No multicollinearity \\
& VIF $(1.061 ; 1.046 ; 1.107)<10$ & \\
Heteroscedasticity test & p-value $(0.755 ; 0.702 ; 0.970)>0.05$ & No heteroscedasticity \\
Autocorrelation test & Asymp. Sig. 2-tailed $(0.761)>0.05$ & No autocorrelation \\
Normality test & Asymp. Sig. 2-tailed $(0.436)>0.05$ & Normal residuals \\
\hline
\end{tabular}

Testing the hypothesis in this study using path analysis aims to examine the direct and indirect effect of e-SERVQUAL and price perception on repurchase intention through customer satisfaction. The test results of direct effect between variables are presented in Table 3.

Table 3 Path Coefficient of Direct Effect and Hypothesis Testing

\begin{tabular}{clcccc}
\hline Hypothesis & \multicolumn{1}{c}{ Direct Effect } & Path Coefficient & t-Value & p-Value & Result \\
\hline H1 & E-SERVQUAL $\rightarrow$ Satisfaction & 0.146 & 2.436 & 0.017 & Accepted \\
H2 & Price $\rightarrow$ Satisfaction & 0.308 & 2.119 & 0.037 & Accepted \\
H3 & E-SERVQUAL $\rightarrow$ Intention & 0.194 & 4.438 & 0.000 & Accepted \\
H4 & Price $\rightarrow$ Intention & 0.419 & 4.000 & 0.000 & Accepted \\
H5 & Satisfaction $\rightarrow$ Intention & 0.295 & 4.026 & 0.000 & Accepted \\
\hline
\end{tabular}

Hypothesis 1 is proven with estimate value of path coefficient of 0.146 with a positive direction, t-value of 2.436 and $p$-value of $0.017<a=0.05$. Positive path coefficient means the e-SERVQUAL affect on customer satisfaction. These results support the research of Jonathan (2013); Laurent (2016). Hypothesis 2 is proven with estimate value of path coefficient of 0,308 with a positive direction, t-value of 2.119 and $p$-value of $0.037<a=0.05$. Positive path coefficient means the price perception affect on customer satisfaction. These results support the research of Kuo \& Tang (2013); Idris 
(2017). Hypothesis 3 is proven with estimate value of path coefficient of 0,194 with a positive direction, t-value of 4.438 and $p$-value of $0.000<a=0.05$. Positive path coefficient means the e-SERVQUAL affect on repurchase intention. These results support the research of J onathan (2013); Laurent (2016); Akbar \& Djatmiko (2016); Idris (2017). Hypothesis 4 is proven with estimate value of path coefficient of 0.419 with a positive direction, t-value of 4.000 and $p$-value of $0.000<a=0.05$. Positive path coefficient means the price perception affect on repurchase intention. These results support the research of Zeithaml et al. (2017); Faradiba (2013); Idris (2017). Hypothesis 5 is proven with estimate value of path coefficient of 0,295 with a positive direction, $t-$ value of 4.026 and $p$-value of $0.000<a=0.05$. Positive path coefficient means the customer satisfaction affect on repurchase intention. These results support the research of Qin \& Prybutok (2009).

Table 4 Result of Sobel Test - Effect of e-SERVQUAL on Repurchase Intention through Customer Satisfaction

\begin{tabular}{|c|c|c|c|c|c|}
\hline Path & $\begin{array}{c}\text { Standardized } \\
\text { Coefficients }\end{array}$ & $\begin{array}{l}\text { Standard } \\
\text { Error }\end{array}$ & $\begin{array}{c}\text { Sobel Test } \\
\text { Statistic }\end{array}$ & $\begin{array}{l}\text { One-Tailed } \\
\text { Probability }\end{array}$ & $\begin{array}{l}\text { Two-Tailed } \\
\text { Probability }\end{array}$ \\
\hline E-SERVQUAL $\rightarrow$ & $A=0.146$ & $\mathrm{SE}_{\mathrm{A}}=0.060$ & & & \\
\hline $\begin{array}{l}\text { Satisfaction } \\
\text { Satisfaction } \rightarrow \\
\text { Intention }\end{array}$ & $B=0.355$ & $\mathrm{SE}_{\mathrm{B}}=0.077$ & 2.152 & 0.016 & 0.031 \\
\hline
\end{tabular}

Sources: Result of Online Sobel Calculator

Mediation test is aimed to detect position of mediation variables in model, to test the hypothesis of the six and seven, sobel test was used to examine the relationship existing mediating variables in the hypothesis. Testing of hypothesis 6 aims to examine the indirect effect of e-SERVQUAL on repurchase intention through customer satisfaction. Results of Sobel calculator online are presented are presented in Table 4.

Table 5 Result of Sobel Test - Effect of Price Perception on Repurchase Intention through Customer Satisfaction

\begin{tabular}{lccccc}
\hline \multicolumn{1}{c}{ Path } & $\begin{array}{c}\text { Standardized } \\
\text { Coefficients }\end{array}$ & $\begin{array}{c}\text { Standard } \\
\text { Error }\end{array}$ & $\begin{array}{c}\text { Sobel Test } \\
\text { Statistic }\end{array}$ & $\begin{array}{c}\text { One-Tailed } \\
\text { Probability }\end{array}$ & $\begin{array}{c}\text { Two-Tailed } \\
\text { Probability }\end{array}$ \\
\hline $\begin{array}{l}\text { Price } \rightarrow \text { Satisfaction } \\
\begin{array}{l}\text { Satisfaction } \rightarrow \\
\text { Intention }\end{array}\end{array}$ & $\begin{array}{c}\mathrm{A}=0.308 \\
\mathrm{~B}=0.418\end{array}$ & $\begin{array}{c}\mathrm{SE}_{\mathrm{A}}=0.145 \\
\mathrm{SE}_{\mathrm{B}}=0.114\end{array}$ & 1.838 & 0.033 & 0.066 \\
\hline $\begin{array}{l}\text { Sources: Result of Online Sobel Calculator } \\
\text { Sources }\end{array}$ & & & & & \\
\hline
\end{tabular}

Hypothesis 6 is proven. Results of sobel test show sobel test statistic 2.152 and $p-$ value (two-tailed probability) $0.031<a=0.05$. This indicates customer satisfaction mediates the effect of e-SERVQUAL on repurchase intention. These results support the research of Kuo \& Tang (2013); Idris (2017). This finding also supports the research conducted by Jonathan (2013); Laurent (2016) that the effect of e-SERVQUAL on customer loyalty mediated by customer satisfaction.

Testing of hypothesis 7 aims to examine the indirect effect of price perception on repurchase intention through customer satisfaction. Results of sobel calculator online 
are presented are presented in Table 5 . Hypothesis 7 is rejected, results of sobel test show sobel test statistic 1.838 and $p$ value (two-tailed probability) $0.066>a=0.05$. This indicates customer satisfaction cannot mediate the effect of price perception on repurchase intention. The findings of this study do not support the research conducted by Kuo \& Tang (2013); Idris (2017).

\section{Conclusion}

The findings of this study that Shopee e-SERVQUAL, price perception, and customer satisfaction have positive and significant effect on repurchase intention. Results of sobel test show that customer satisfaction mediates the effect of e-SERVQUAL on repurchase intention. However, customer satisfaction cannot mediate the effect of price perception on repurchase intention. Implications of this study, marketing managers must provide good service to customers, because e-SERVQUAL will be able to increase customer satisfaction, and then customer satisfaction will create repurchase intention. In purchasing an online factor price can directly affect repurchase intention, without through satisfaction because customers are more affected by online service quality.

\section{References}

Akbar, A. A., \& Djatmiko, T. (2016). Pengaruh e-Service Quality terhadap E-Customer Satisfaction dan E-Customer Loyalty pada lazada.co.id. E-Proceeding of Management, 3(1), 142-150.

Chase, R. B., \& Aquilano, N. J. (2004). Operations Management for Competitive Advantage (10th ed.). McGraw-Hill.

Clemes, M. D., Wu, J. H.-C., Hu, B.-D., \& Gan, C. (2009). An Empirical Study of Behavioral Intentions in the Taiwan Hotel Industry. Innovative Marketing, 5(3), 30-50.

East, R., Gendall, P., Hammond, K., \& Lomax, W. (2005). Consumer Loyalty: Singular, Additive or Interactive? Australasian Marketing Journal, 13(2), 10-26. http://doi.org/10.1016/S1441-3582(05)70074-4

Faradiba, S. R. T. A. (2013). Analisis Pengaruh Kualitas Produk, Harga, Lokasi dan Kualitas Pelayanan terhadap Minat Beli Ulang Konsumen (Studi pada Warung Makan "Bebek Gendut" Semarang). Diponegoro Journal of Management, 2(3), 1-11.

Hellier, P. K., Geursen, G. M., Carr, R. A., \& Rickard, J. A. (2003). Customer Repurchase Intention: A General Structural Equation Model. European Journal of Marketing, 3711/12), 1762-1800. http://doi.org/10.1108/03090560310495456

Ho, C.-I., \& Lee, Y.-L. (2007). The Development of an e-Travel Service Quality Scale. Tourism Management, 28(6), 1434-1449. http://doi.org/10.1016/j.tourman.2006.12.002

Idris, A. M. (2017). Pengaruh Citra Perusahaan, Kualitas Layanan, dan Persepsi Harga terhadap Minat Beli Ulang melalui Kepuasan Pelanggan sebagai Variabel Intervening (Studi pada Penumpang New Atlas Taksi Semarang). Diponegoro Journal of Management, 6(3), 1-8.

Jonathan, H. (2013). Analisis Pengaruh E-Service Quality terhadap Customer Satisfaction yang Berdampak pada Customer Loyalty PT Bayu Buana Travel Tbk. The Winners, 14(2), 104-112.

Kotler, P., \& Keller, K. L. (2016). Marketing Management (15th ed.). London: Pearson Education, Inc. 
Kuo, C.-W., \& Tang, M.-L. (2013). Relationships among Service Quality, Corporate Image, Customer Satisfaction, and Behavioral Intention for the Elderly in High Speed Rail Services. Journal of Advanced Transportation, 47(5), 512-525. http://doi.org/10.1002/atr.179

Laurent, F. (2016). Pengaruh E-Service Quality terhadap Loyalitas Pelanggan Go-Jek melalui Kepuasan Pelanggan. AGORA, 4(2), 95-100.

Martin-Consuegra, D., Molina, A., \& Esteban, Á. (2007). An Integrated Model of Price, Satisfaction and Loyalty: An Empirical Analysis in the Service Sector. Journal of Product and Brand Management, 16(7), 459-468. http://doi.org/10.1108/10610420710834913

Meidita, Y., Suprapto, S., \& Rokhmawati, R. I. (2018). Pengaruh Kualitas Layanan terhadap Kepuasan, Kepercayaan dan Loyalitas Pelanggan pada E-Commerce (Studi Kasus: Shopee). Jurnal Pengembangan Teknologi Informasi Dan IImu Komputer, 2(11), 5682-5690.

Oliver, R. L. (1999). Whence Consumer Loyalty? Journal of Marketing, 63(4_Suppl1), 3344. http://doi.org/10.1177/00222429990634s105

Parasuraman, A., Zeithaml, V. A., \& Malhotra, A. (2005). E-S-QUAL: A Multiple-Item Scale for Assessing Electronic Service Quality. Journal of Service Research, 7(3), 213-233. http://doi.org/10.1177/1094670504271156

Payne, A. (1993). The Essence of Services Marketing. Prentice Hall.

Qin, H., \& Prybutok, V. R. (2009). Service Quality, Customer Satisfaction, and Behavioral Intentions in Fast-Food Restaurants. International Journal of Quality and Service Sciences, 1(1), 78-95. http://doi.org/10.1108/17566690910945886

Srivastava, K., \& Sharma, N. K. (2013). Service Quality, Corporate Brand Image, and Switching Behavior: The Mediating Role of Customer Satisfaction and Repurchase Intention. Services Marketing Quarterly, 34(4), 274-291. http://doi.org/10.1080/15332969.2013.827020

Tjiptono, F., \& Chandra, G. (2016). Service, Quality dan Satisfaction (4th ed.). Yogyakarta: Andi Publisher.

Zeithaml, V. A., Bitner, M. J., \& Gremler, D. (2017). Services Marketing: Integrating Customer Focus Across the Firm (7th ed.). McGraw-Hill Education.

Zeithaml, V. A., Parasuraman, A., \& Malhotra, A. (2002). Service Quality Delivery through Web Sites: A Critical Review of Extant Knowledge. Journal of the Academy of Marketing Science, 304), 362-375. http://doi.org/10.1177/009207002236911 